\section{A randomized trial of occlusal adjustment in the treatment of periodontitis patients}

\author{
Burgett FG, Ramfjord SP, Nissle RR, Morrison EC, Charbeneau TD and Caffesse \\ $R G$. A randomized trial of occlusal adjustment in the treatment of periodontitis \\ patients. J Clin Periodontal 1992; 19: 381-387.
}

Abstract. The purpose of the randomized clinical trial was to test; (1) the influence of occlusal adjustment (OA) in association with periodontal therapy on attachment levels, pocket depth, and tooth mobility, (2) whether OA was of greater significance in non-surgically treated periodontal defects, and (3) whether initial tooth mobility or disease severity had an affect on post-treatment attachment levels following OA. After hygienic-phase therapy, 50 patients received OA/No OA according to random assignment; 22 patients received an $\mathrm{OA}$ and 28 were not adjusted. 2 months after OA, either modified Widman flap surgery or scaling and root planing by a periodontist were done according to random assignment within each patient in a split-mouth design. Following active treatment patients were maintained with prophylaxis done every 3 months and scored annually. For the analysis of this two-year data, a repeated measures analysis of variance was performed using attachment level change and pocket depths as outcome indicators. There was significantly greater gain of clinical periodontal attachment in patients who received an OA compared to those who did not. Both the surgically and non-surgically treated sides of the mouth responded similarly to OA. There was no affect of OA on the response in pocket depth, nor did initial tooth mobility or initial periodontal disease severity influence the response to OA.
F. G. Burgett', S. P. Ramfjord', R. R. Nissle', E. C. Morrison ${ }^{2}$, T. D. Charbeneau ${ }^{3}$ and

\section{R. G. Caffesse ${ }^{2}$}

${ }^{1}$ University of Michigan, School of Dentistry, Periodontics, Ann Arbor, Michigan 48109, USA; ${ }^{2}$ University of Texas, Dental Branch, Health Science Center at Houston, P. O. Box 20068, Houston, Texas 77225, USA; Baylor University, Department of Periodontics, 3302 Gaston Avenue, Dallas, Texas 75246, USA
Key words: occlusal adjustment; clinical trial; periodontal surgery; periodontal scaling and root planing; probing periodontal attachment level.

Accepted for publication 8 April 1991
Occlusal adjustment in periodontal therapy has received scant attention during recent years (Ramfjord \& Ash 1981) as trends in reserach have focused on micro-organisms as the direct cause of periodontal disease in its various forms (Lang et al. 1985). However, the possibility exists that occlusal function may have a significant influence on the balance between the host and the parasite at the dentogingival junction. Occlusal factors could influence periodontal metabolism and defense mechanisms and thereby, possibly play a role both in etiology of the disease and healing after treatment.

The precise nature of such a role is yet to be identified. Experimental studies in animals indicate that trauma from occlusion does not initiate or aggravate gingivitis (Svanberg 1974), but may facilitate the progress of attachment loss in periodontitis (Lindhe \& Svanberg 1974, Nyman, Lindhe \& Ericsson 1978, Ericsson \& Lindhe 1982) or at least, result in more bone resorption (Meitner
1975, Polson et al. 1976). In the treatment of periodontitis in dogs, no affect on healing or maintenance of attachment levels was found in the comparison of jiggled and non-jiggled teeth in dogs with adequate plaque control (Lindhe \& Ericsson 1976). However, it was mentioned that more connective tissue reattachment and bone regeneration may have occurred around the nonjiggled teeth. In monkeys it was observed (Polson et al. 1976) that when experimental jiggling of teeth was stopped, a significant gain of alveolar bone occurred after treatment but no such reversal of bone loss occurred in the presence of periodontitis with active inflammation. In another study (Kantor et al. 1976), after removal of inflammation and traumatic factors, found bone regenerated without gain of attachment.

Findings reported from patients regarding the response of mobile and nonmobile teeth to periodontal surgery have been conflicting with some report- ing a similar response (Glickman et al. 1966, Nyman et al. 1975) while others finding a more favorable periodontal attachment level response in firm teeth (Fleszar et al. 1980). Furthermore, Ericsson \& Lindhe (1984) stated that: "Teeth from which the trauma was removed seemed to have more favorable healing, i.e., gain of connective tissue attachment than the contralateral hypermobile teeth". They further suggested that on the basis on reports by Lindhe \& Ericsson (1976) and Fleszar et al. (1980): "It seems reasonable to suggest that while permanent increased (but not progressive) mobility has no influence on the development of periodontitis, healing following surgical treatment of periodontal disease may be more advantageous in non-mobile than in mobile teeth". It has been reported that the vast majority of initially hypermobile teeth in patients with periodontitis after periodontal treatment but without occlusal adjustment show no increase in mobility in long term follow- 
up (Lindhe \& Nyman 1975, Nyman \& Lindhe 1976). However, it has also been shown that adjustment of occlusion can reduce mobility significantly (Muhlemann et al. 1957, Vollmer \& Ratetischak 1975 ) and that tooth mobility will increase with loss of support for the teeth (Muhlbradt 1972, Renggli \& Muhlemann 1970).

In dogs experimental trauma from occlusion had no influence on the recurrence of periodontitis (Ericsson \& Lindhe 1977, Lindhe \& Ericsson 1982). Repopulation by bacteria in traumatized and non-traumatized teeth after periodontal treatment was found to be similar but the loss of attachment was greater for the traumatized than for the non-traumatized teeth (Kaufman et al. 1984).

It appears from this brief review of the literature that the role of occlusal adjustment in periodontal treatment has not been determined. Occlusal adjustment may be a factor in the healing of periodontal defects, especially bony defects, and in maintenance of teeth following periodontal treatment - non-surgical or surgical.

While results from periodontal clinical trials offer good evidence as to the comparative result of different surgical and non-surgical modalitis of periodontal treatment, the role of occlusal adjustment in the therapy has not been tested.

The purpose of this randomized clinical trial was to test: (1) the influence of occlusal adjustment in association with conventional periodontal therapy on attachment levels, pocket depths, and tooth mobility; (2) whether the effects of occlusal adjustment differed in nonsurgically compared with surgically treated periodontal pockets; (3) whether initial tooth mobility had an influence on the periodontal response to occlusal adjustment.

\section{Material and Methods}

Entry criteria for the study were that patients be adults diagnosed as having moderate to advanced periodontitis, be willing to participate in the trial, and be likely to remain living in the area to participate in maintenance care and yearly rescorings. While more patients have been entered to date, this interim report will be limited to the 50 patients who had completed two years of followup at the time of this analysis of the data. The mean age was 44.2 years

Table 1. Mean change in attachment level (SD)

\begin{tabular}{llll}
\hline & Baseline & Year 1 change & Year 2 change \\
\hline $\begin{array}{l}\text { Occlusal adjustment }(n=22) \\
\quad \text { scaling and root planing }\end{array}$ & $-3.52(0.81)(\mathrm{mm})$ & $0.43(0.56)(\mathrm{mm})$ & $0.46(0.66)(\mathrm{mm})$ \\
modified Widman flap & $-3.48(0.76)$ & $0.18(0.52)$ & $0.37(0.68)$ \\
\cline { 2 - 4 } mean & $-3.50(0.78)$ & $0.32(0.54)$ & $0.42(0.67)$ \\
$\begin{array}{l}\text { No occlusal adjustment }(n=28) \\
\text { scaling and root planing }\end{array}$ & $-3.44(1.20)$ & $-0.04(0.39)$ & $0.08(0.53)$ \\
modified Widman flap & $-3.50(1.19)$ & $-0.11(0.49)$ & $-0.03(0.54)$ \\
mean & $-3.47(1.20)$ & $-0.07(0.44)$ & $0.02(0.53)$ \\
\hline
\end{tabular}

(s.d.=11.2) with a range of 25 to 69 years. The number of teeth present at entry for these patients was 27.0 (s.d.= 2.5 ) with a range of 20 to 32 teeth, and the mean attachment loss was $3.39 \mathrm{~mm}$ (s.d.=1.04). Of the 50 patients, 29 were females and 21 males. At entry each patient was assigned randomly to an occlusal adjustment or to no occlusal adjustment and within each patient, either modified Widman flap surgery or scaling and root planing was assigned randomly to each side of the patient's mouth. Random assignment was made via a computer generated list of random numbers.

Patients meeting the entry criteria received initial hygienic phase treatment by a dental hygienist. This treatment consisted of periodontal scaling and root planing, smoothing of restorations, polishing of the teeth, oral hygiene intructions, and fluoride treatments (Morrison et al. 1980). Initial treatment required 4 or 5 visits. These patients assigned to the occlusal adjustment group received the adjustment by one periodontist (S. P. R.) according to the criteria described in the textbook, $O c$ clusion, by Ramfjord \& Ash, 1981. In general terms the adjustment was directed toward obtaining even and stable tooth contacts in centric relation, free-

Occlusal Adjustment
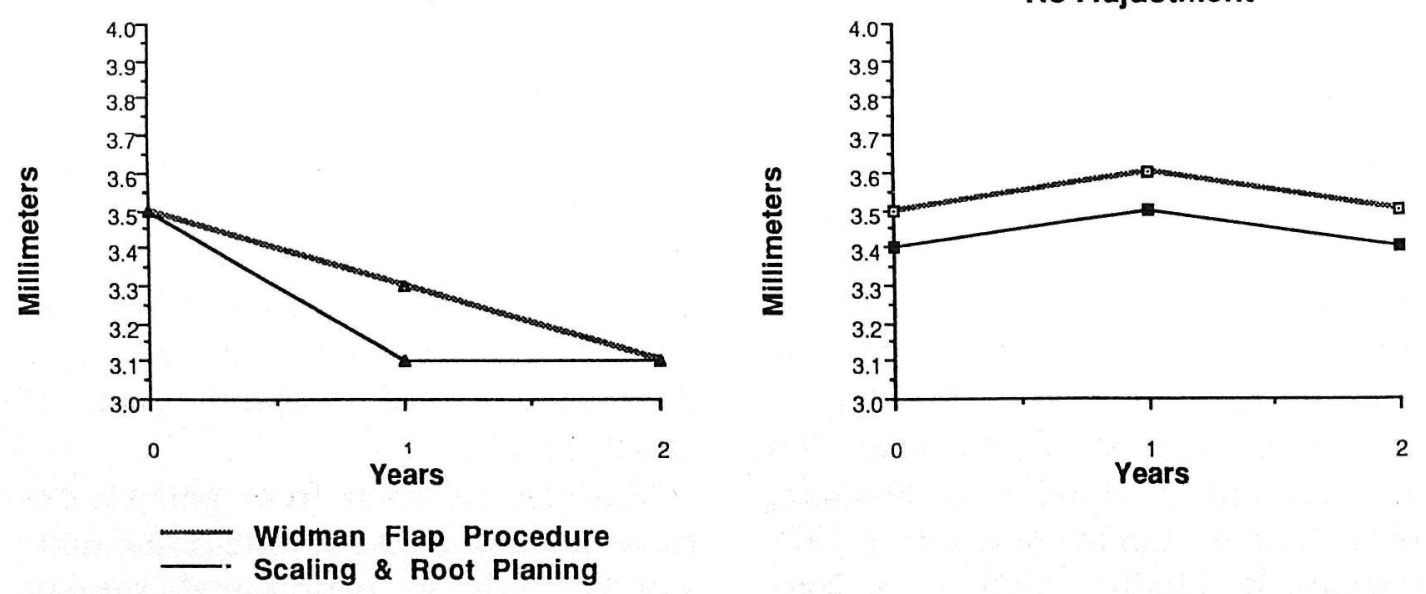

dom in centric, smooth gliding contacts in centric and eccentric mandibular motion, and elimination of balancing side interferences. After the adjustment of patients assigned to the adjustment group, all the patients received modified Widman flap surgery on one side of the mouth and periodontal scaling and root planing on the other according to the assignments made on entry to the study. The details of each of these approaches to therapy have been published previously (Ramfjord \& Nissle 1974, Hill et al. 1981).

\section{Statistical analysis}

All statistical analysis was done via a repeated measures analysis of variance using attachment level response as the outcome variable except for the analysis of pocket depth which utilized pocket depth response as the outcome variable. In consideration of tooth mobility, a grouping factor was created by dividing the patient population into two; the half with more initial tooth mobility and the half with less initial tooth mobility. The response within patients among teeth of various initial mobilities was not evaluated. For the disease severity analysis, only those patients with at least one pocket of greater than $6 \mathrm{~mm}$ initially on

Fig. 1. Mean loss of attachment. 
Table 2. Repeated measures analysis of variance for mean change in attachment level

\begin{tabular}{lccccc}
\hline Source & $\begin{array}{c}\text { Sum of } \\
\text { Squares }\end{array}$ & $\begin{array}{c}\text { Degrees of } \\
\text { freedom }\end{array}$ & $\begin{array}{c}\text { Mean } \\
\text { square }\end{array}$ & $F$ & $\begin{array}{c}\text { Tail } \\
\text { probability }\end{array}$ \\
\hline mean & 5.53 & 1 & 5.53 & 6.12 & 0.0169 \\
OA/NoOA (O) & 7.17 & 1 & 7.17 & 7.94 & 0.0070 \\
error & 43.37 & 48 & 0.90 & & \\
MWF/SRP (W) & 0.81 & 1 & 0.81 & 12.46 & 0.0009 \\
OW & 0.07 & 1 & 0.07 & 1.09 & 0.3020 \\
error & 3.11 & 48 & 0.06 & & \\
time (T) & 0.53 & 1 & 0.53 & 2.46 & 0.1237 \\
OT & 0.00 & 1 & 0.00 & 0.01 & 0.9142 \\
error & 10.28 & 48 & 0.21 & & \\
WT & 0.04 & 1 & 0.04 & 2.69 & 0.1074 \\
OWT & 0.13 & 1 & 0.13 & 7.91 & 0.0071 \\
error & 0.77 & 48 & 0.02 & & \\
\hline
\end{tabular}

Table 3. Mean pocket depth (SD)

\begin{tabular}{llll}
\hline & Baseline & Year 1 & Year 2 \\
\hline $\begin{array}{l}\text { Occlusal adjustment }(n=22) \\
\text { scaling and root planing }\end{array}$ & $3.66(0.75)(\mathrm{mm})$ & $3.12(0.44)(\mathrm{mm})$ & $3.08(0.41)(\mathrm{mm})$ \\
modified Widman flap & $3.64(0.61)$ & $2.81(0.30)$ & $2.90(0.33)$ \\
\cline { 2 - 4 } mean & $3.65(0.78)$ & $2.97(0.37)$ & $2.99(0.37)$ \\
No occlusal adjustment $(n=28)$ & & & \\
$\quad \begin{array}{l}\text { scaling and root planing } \\
\text { modified Widman flap }\end{array}$ & $3.58(0.58)$ & $3.05(0.53)$ & $3.04(0.43)$ \\
mean & $3.62(0.68)$ & $2.72(0.38)$ & $2.89(0.41)$ \\
\hline
\end{tabular}

both sides of the mouth were included. The repeated measures ANOVA allowed analysis of the main effects in the model plus interactions between and among the main effects. It also allowed inclusion into a single analysis 'within patient' factor such as comparison between the side of the mouth treated by modified Widman flap and the side treated by scaling and root planing, and among patient factors such as comparison of the patients treated by occlusal adjustment and the patients not adjusted.

\section{Results}

The mean clinical attachment levels responded more favorably in the patients who received occlusal adjustment than in the non-adjusted patients. The difference in attachment level change was $0.39 \mathrm{~mm}$ at year one and $0.40 \mathrm{~mm}$ at year 2 in favor of occlusal adjustment (Table 1). Mean clinical attachment levels for both groups of patients are depicted graphically (Fig. 1) which shows a gain of attachment both for the modified Widman flap quadrants and

Table 4. Repeated measures analysis of variance for mean pocket depth

\begin{tabular}{lrcccc}
\hline Source & $\begin{array}{c}\text { Sum of } \\
\text { Squares }\end{array}$ & $\begin{array}{c}\text { Degrees of } \\
\text { freedom }\end{array}$ & $\begin{array}{c}\text { Mean } \\
\text { square }\end{array}$ & $F$ & $\begin{array}{c}\text { Tail } \\
\text { probability }\end{array}$ \\
\hline mean & 2985.78 & 1 & 2985.78 & 2918.55 & 0.0001 \\
OA/NoOA (O) & 0.22 & 1 & 0.22 & 0.21 & 0.6485 \\
error & 49.11 & 48 & 1.02 & & \\
MWF/SRP (W) & 1.90 & 1 & 1.90 & 15.20 & 0.0003 \\
OW & 0.00 & 1 & 0.00 & 0.04 & 0.8522 \\
error & 6.01 & 48 & 0.13 & & \\
time (T) & 30.03 & 2 & 15.01 & 87.35 & 0.0001 \\
OT & 0.04 & 2 & 0.02 & 0.11 & 0.8977 \\
error & 16.50 & 96 & 0.17 & & \\
WT & 1.33 & 2 & 0.66 & 28.75 & 0.0001 \\
OWT & 0.02 & 2 & 0.01 & 0.52 & 0.5991 \\
error & 2.22 & 96 & 0.02 & & \\
\hline
\end{tabular}

the scaling and root planing quadrants with occlusal adjustment while little change occurred in the non-adjusted patients.

The sides of the patients' mouths treated by scaling and root planing had a slightly more favorable attachment level response than the sides of the patients' mouths receiving modified Widman flap surgery. At year 1 , the difference was $0.16 \mathrm{~mm}$ and at year 2 , it was $0.10 \mathrm{~mm}$ (Table 1).

A repeated measure analysis of variance with one grouping factor; patients receiving occlusal adjustment versus those not adjusted, and two within factors; the sides of the mouth receiving modified Widman flap procedure versus those receiving periodontal scaling and root planing and time, was used in the statistical analysis. The outcome variable was mean change in attachment level.

In this statistical model, the main effect of patients receiving occlusal adjustment (OA/No OA) versus the not adjusted was significant $(p=0.007)$. See Table 2. The main effect of the sides of the mouth receiving modified Widman flap surgery versus periodontal scaling and root planing (WFP/SRP) was significant $(p=0.0009)$. The interaction between all three effects in the model; OA/ No OA, WFP/SRP, and time, while significant explained very little of the total variation in the model. The interaction of the treatments and time can be seen in the graph (Fig. 1) where while there is a difference in attachment level response between the 1st and the 2nd year, the magnitude of difference in the between patient grouping factor, occlusal adjustment, remained almost the same. On the other hand, very little difference in response between scaling and root planing and modified Widman flap was found at year 2 .

In consideration of pocket depth response, the adjusted patients had less than $0.1 \mathrm{~mm}$ more mean pocket depth reduction than the non-adjusted. On the sides of the mouths treated with modified Widman flap, the pocket depths were reduced by $0.86 \mathrm{~mm}$ at year one and $0.73 \mathrm{~mm}$ at year 2 while with scaling and root planing, a reduction occurred of $0.53 \mathrm{~mm}$ and $0.56 \mathrm{~mm}$ respectively (Table 3). Using repeated measures analysis of variance with pocket depth (Table 4) as the outcome variable, there was no significant difference in pocket response between the adjusted and nonadjusted patients. The difference in 


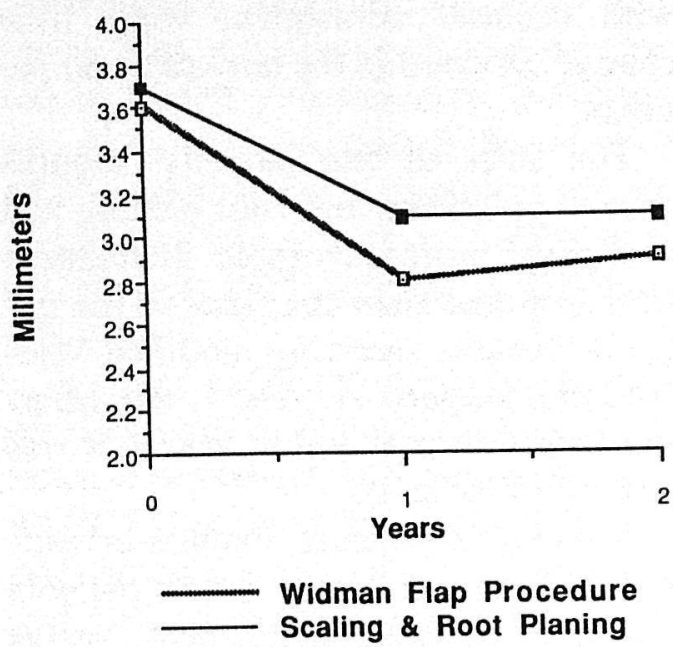

Fig. 2. Mean pocket depth.

pocket depth reduction between the sides treated by modified Widman flap and the sides treated by periodontal scaling and root planing was significant $(p=0.0003)$. Surgical treatment resulted in greater pocket depth reduction. Also statistically significant were time and the interaction between time and mouth side treatment. As can be seen on the graph (Fig. 2) there is a tendency for reduction of the difference between the sides mouth pocket depth response between year one and year two. However, neither occlusal adjustment nor any in-
Occlusal Adjustment

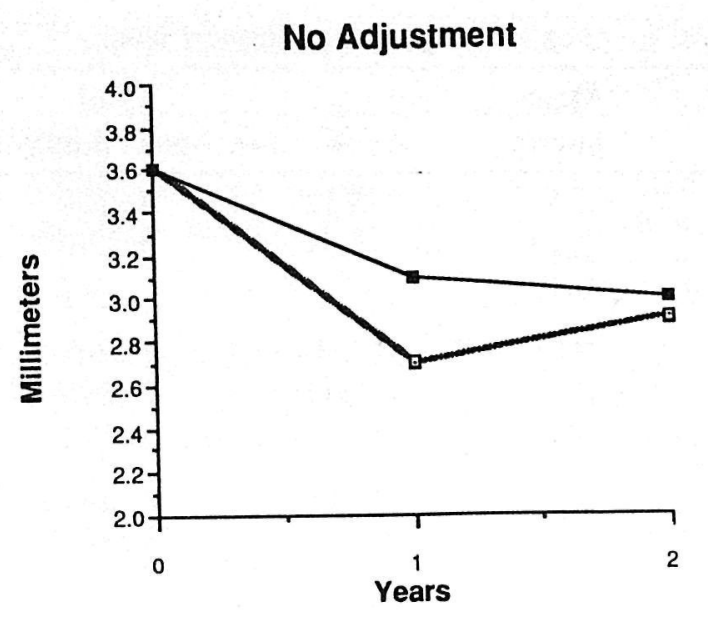

teraction involving occlusal adjustment were significant.

There were no significant differences in clinical periodontal attachment level change after treatment among the various levels of initial pocket depth (1-3 $\mathrm{mm}, 4-6 \mathrm{~mm}$, and $>6 \mathrm{~mm}$ ) between the adjusted and non-adjusted patients regardless of modality of therapy (Table $5)$ although the differences approached significance $(p=0.0584)$. As with our previous studies (Knowles et al. 1979, Ramfjord et al. 1987) initially deeper pockets gain more attachment with

Table 5. Repeated measures analysis of variance for mean change in attachment level (severity)

\begin{tabular}{|c|c|c|c|c|c|}
\hline Source & $\begin{array}{l}\text { Sum of } \\
\text { Squares }\end{array}$ & $\begin{array}{l}\text { Degrees of } \\
\text { freedom }\end{array}$ & $\begin{array}{l}\text { Mean } \\
\text { square }\end{array}$ & $F$ & $\begin{array}{c}\text { Tail } \\
\text { probability }\end{array}$ \\
\hline mean & 13754.17 & 1 & 13754.17 & 3029.83 & 0.0001 \\
\hline $\mathrm{OA} / \mathrm{NoOA}(\mathrm{O})$ & 17.12 & 1 & 17.12 & 3.82 & 0.0584 \\
\hline error & 161.29 & 36 & 4.48 & & \\
\hline MWF/SRP (W) & 0.01 & 1 & 0.01 & 0.02 & 0.8935 \\
\hline OW & 0.05 & 1 & 0.05 & 0.10 & 0.7504 \\
\hline error & 16.99 & 36 & 0.47 & & \\
\hline severity (S) & 2063.97 & 2 & 1031.99 & 989.58 & 0.0001 \\
\hline OS & 1.33 & 2 & 0.66 & 0.64 & 0.5322 \\
\hline error & 75.09 & 72 & 1.04 & & \\
\hline WS & 1.90 & 2 & 0.95 & 2.14 & 0.1246 \\
\hline WSO & 0.18 & 2 & 0.09 & 0.20 & 0.8207 \\
\hline error & 31.89 & 72 & 0.44 & & \\
\hline time $(\mathrm{T})$ & 39.61 & 2 & 19.81 & 17.02 & 0.0001 \\
\hline OT & 7.74 & 2 & 3.87 & 3.33 & 0.0415 \\
\hline error & 83.77 & 72 & 1.16 & & \\
\hline WT & 0.14 & 2 & 0.07 & 0.45 & 0.6382 \\
\hline WTO & 0.35 & 2 & 0.17 & 1.13 & 0.3295 \\
\hline error & 11.08 & 72 & 0.15 & & \\
\hline ST & 66.17 & 4 & 16.54 & 82.79 & 0.0001 \\
\hline WTO & 0.57 & 4 & 0.14 & 0.71 & 0.5878 \\
\hline error & 28.77 & 144 & 0.20 & & \\
\hline WST & 1.46 & 4 & 0.37 & 3.22 & 0.0144 \\
\hline WTO & 0.11 & 4 & 0.03 & 0.24 & 0.9147 \\
\hline error & 16.33 & 144 & 0.11 & & \\
\hline
\end{tabular}

treatment. In the repeated measures analysis of variance, severity is very significant $(p=0.0001)$. Time and the severity-time interaction were significant. Time was significant because of a difference in probing attachment level response between year 1 and year 2 . The severity-time interaction significance relates to the difference in response in the severity levels at the 1- and 2-year examinations. The statistical significant finding involving time, and involving the interaction term of time and severity add little to interpretation of the data. The interaction term of greatest interest is those involving occlusal adjustment. In this analysis no interaction involving OA/NoOA was significant. All three initial pocket depth categories $(1-3 \mathrm{~mm}$, 4-6 $\mathrm{mm}$, and $>6 \mathrm{~mm}$ ) responded similarly, i.e., the adjusted patients had a more favorable probing attachment level response (Fig. 3).

Tooth mobility was scored with the criteria used in our previous studies (Fleszar et al. 1980). More than half of the teeth in this study population showed increased mobility initially. The mean mobility for all of the teeth of all the patients was 0.75 and for the purpose of analysis both the adjusted and non-adjusted patients were divided into 2 subgroups; those with mean mobility of $<0.75$ and $>0.75$ (Table 6). There was a significant difference between the attachment level response between the adjusted patients and those not adjusted $(p=0.045)$ in this model just including the sites with 4-6 mm of attachment loss. When the patients were categorized by tooth mobility, the greatest difference in attachment level response occurred primarily between the adjusted and non-adjusted patients with less teeth mobility (Fig. 4). Only the teeth with $4-6 \mathrm{~mm}$ of attachment loss were included since these were the sites where it was felt that a difference would most likely be found.

\section{Discussion}

Results from this clinical trial indicate that occlusal adjustment may have some value as an adjunct to conventional periodontal therapy. Surprisingly, we did not find any significant difference in reduction of tooth mobility between the adjusted and the not adjusted group. In contrast to the paper by Fleszar et al. (1980), the variation in attachment levels did not relate to the initial tooth mobility. 
Occlusal Adjustment

\section{No Adjustment}
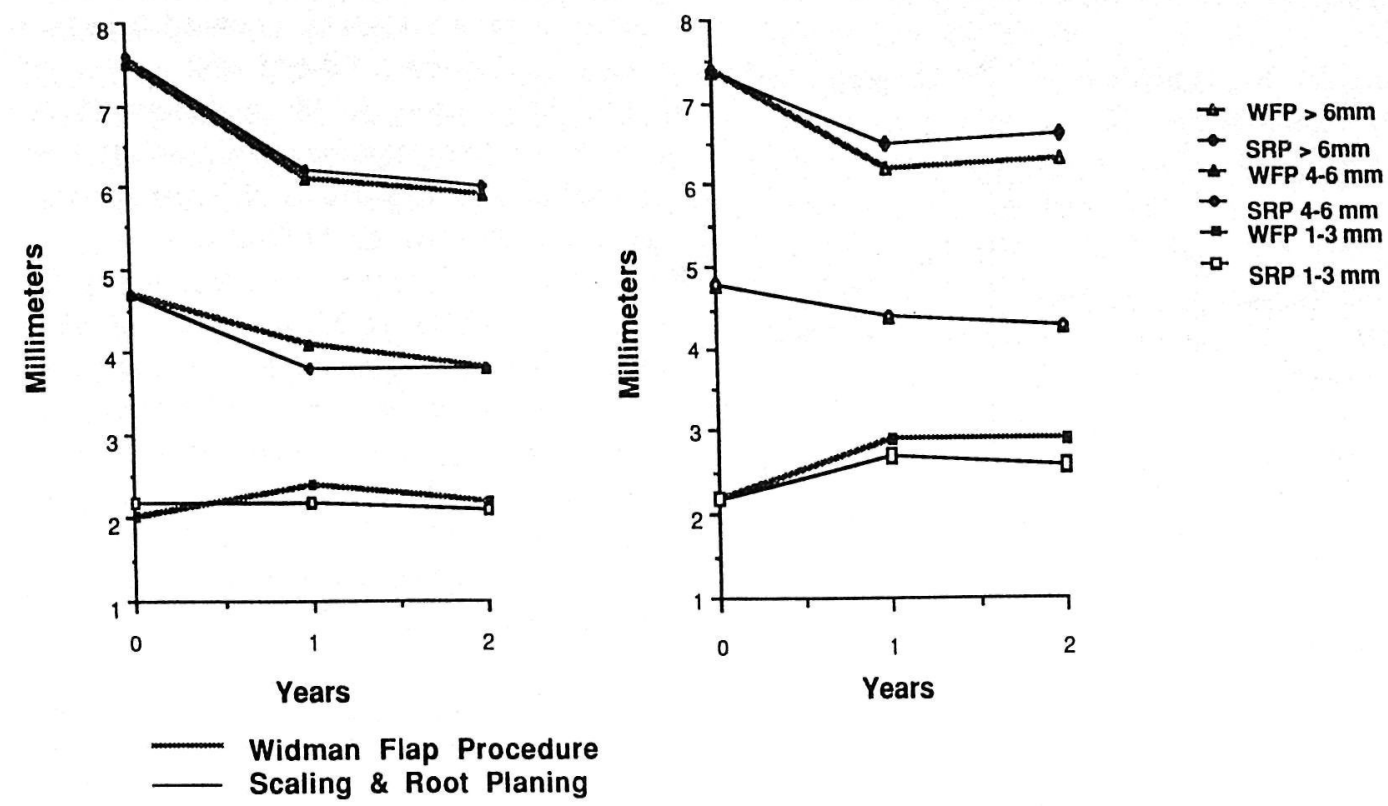

Fig. 3. Mean loss of attachment.

The more favorable response with regards to clinical attachment levels with occlusal adjustment than without, has no explanation on the basis of current knowledge. Probing attachment with a light force (18-22 ponds according to testing of the individual who did the probing) will not necessarily correspond to connective tissue attachment, but is related to the firmness (collagen contact and degree of inflammation) in the soft tissue wall of the pocket. While it has been documented that more bone may regenerate after elimination of trau-

matic forces and reduction of inflammation (Polson et al. 1976, Kantor et al. 1976), it is hard to see how this could affect the penetration of the probe with light force. Previously well documented studies under experimental conditions in animals indicate that no change in clinical attachment level may be anticipated following occlusal therapy (Polson et al. 1976, Kantor et al. 1976). Thus, the favorable response to occlusal therapy in the present study probably related to changes in the soft tissue wall of the pocket, with more favorable heal-

Table 6. Repeated measures analysis of variance for mean change in attachment level for teeth with 4-6 mm attachment loss (mobility)

\begin{tabular}{lrrrrc}
\hline Source & $\begin{array}{c}\text { Sum of } \\
\text { Squares }\end{array}$ & $\begin{array}{c}\text { Degrees of } \\
\text { freedom }\end{array}$ & $\begin{array}{c}\text { Mean } \\
\text { square }\end{array}$ & $F$ & $\begin{array}{c}\text { Tail } \\
\text { probability }\end{array}$ \\
\hline mean & 4426.63 & 1 & 4426.63 & 2221.89 & 0.0001 \\
OA/NoOA (O) & 8.49 & 1 & 8.49 & 4.26 & 0.0450 \\
mobility (M) & 5.62 & 1 & 5.62 & 2.82 & 0.1002 \\
OM & 1.72 & 1 & 1.72 & 0.86 & 0.3577 \\
error & 87.66 & 44 & 1.99 & & \\
MWF/SRP (W) & 0.16 & 1 & 0.16 & 0.47 & 0.4972 \\
OW & 0.36 & 1 & 0.36 & 1.03 & 0.3148 \\
MW & 1.33 & 1 & 1.33 & 3.79 & 0.0578 \\
OMW & 0.03 & 1 & 0.03 & 0.07 & 0.7864 \\
error & 15.37 & 44 & 0.35 & & \\
time (T) & 11.00 & 2 & 5.50 & 16.19 & 0.0001 \\
OT & 1.78 & 2 & 0.89 & 2.62 & 0.0787 \\
MT & 0.56 & 2 & 0.28 & 0.82 & 0.4420 \\
OMT & 0.65 & 2 & 0.32 & 0.96 & 0.3885 \\
error & 29.90 & 88 & 0.34 & & \\
WT & 0.14 & 2 & 0.07 & 1.66 & 0.1953 \\
WTO & 0.09 & 2 & 0.04 & 1.04 & 0.3584 \\
WTM & 0.12 & 2 & 0.06 & 1.36 & 0.2610 \\
WTOM & 0.13 & 2 & 0.06 & 1.51 & 0.2269 \\
error & 3.71 & 88 & 0.04 & & \\
\hline
\end{tabular}

ing and reduction of inflammation after occlusal therapy. The reason for this increased collagen resistance following occlusal adjustment is not apparent at the present. Maybe collagen, enzymes, or metabolites prostoglandins involved in the healing response may be affected by changes in occlusal forces on the teeth. It could also be that the results are artifactual by chance. However, this is not likely since as many as 50 patients were involved in the study, and the experimental conditions were rigidly controlled. All scoring was done by the same person (E. C. M.) who was experienced in clinical scoring and had been calibrated for periodontal scoring. We will report later findings for more patients over a longer time of observation.

\section{Conclusions}

Occlusal adjustment in conjunction with conventional periodontal therapy resulted in a more favorable clinical attachment level for the adjusted than the non-adjusted patients after 2 years.

Occlusal adjustment had no influence on changes in pocket depth over two years following the therapy.

Initial tooth mobility did not affect the clinical attachment response to occlusal adjustment.

Initial severity of the periodontal disease as expressed in pocket depth did not affect the attachment responses to occlusal adjustment.

Periodontal attachment levels on the side of the mouthy treated by modified Widman flap surgery and the side of scaling and root planing responded similarly to occlusal adjustment.

\section{Zusammenfassung}

Behandlung von Patienten mit Parodontitis Der Zweck der randomisierten klinischen Studie war das Testen von: (1) dem Einfluß des okklusalen Einschleifens (OA), in Verbindung mit der Parodontalbehandlung, auf das Attachmentniveau, Taschentiefe und Zahnbeweglichkeit, (2) der eventuellen größeren Signifikanz des OA bei nicht-chirurgisch behandelten parodontalen Defekten, und (3) der Wirkung der initialen Zahnbeweglichkeit bzw. der Schwere der Erkrankung auf das Attachmentniveau nach Behandlung mit OA. Nach der Mundhygienephase erhielten $50 \mathrm{~Pa}$ tienten entsprechend der randomisierten Verteilung ein okklusales Einschleifen oder kein okklusales Einschleifen. 22 Patienten erhielten ein okklusales Einschleifen und 28 wurden nicht adjustiert. 2 Monate nach der OA wurden entsprechend der randomisierten 
Occlusal Adjustment

Mean Mobility

$<0.75$

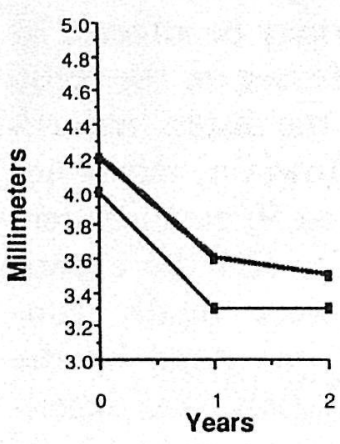

$>0.75$

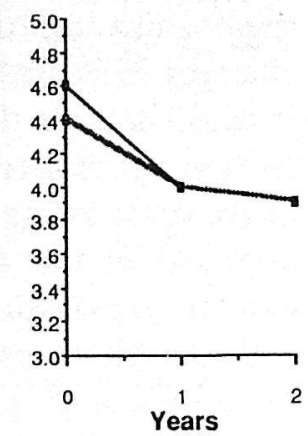

$<0.75$
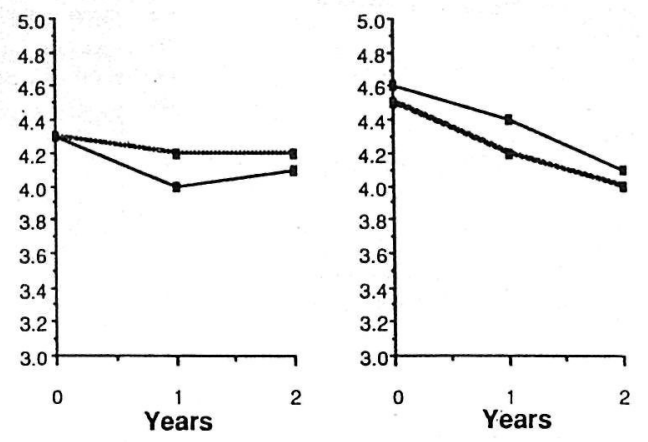

Widman Flap Procedure Scaling \& Root Planing

Fig. 4. Mean loss of attachment (initial loss of attachment 4-6 mm).

Verteilung nach einem Split-Mouth-Design von einem Parodontologen entweder ein Scaling mit Wurzelglättung oder eine modifizierte Widman-Lappen-OP durchgeführt. Nach dieser Behandlungsphase wurden die Patienten einer Erhaltungstherapie mit dreimonatiger Prophylaxe unterzogen. Die Messungen wurden jährlich vorgenommen. Zur Analyse dieser Zwei-Jahres-Daten wurde unter Berücksichtigung der Veränderung des Attachmentniveaus und der Taschentiefe als Ergebnisindikatoren eine wiederholte Varianzanalyse der Meßwerte durchgeführt. Im Vergleich zu den Patienten, die kein OA erhielten, gab es bei Patienten, die ein OA erhielten, einen signifikant höheren klinischen parodontalen Attachmentgewinn. Sowohl die chirurgisch als auch die nicht-chirurgisch behandelten Parodontien des Mundes reagierten auf das OA ähnlich. Es gab weder eine Auswirkung der OA auf die Veränderung der Taschentiefe, noch wurde die Reaktion auf OA durch die initiale Zahnbeweglichkeit oder initiale Schwere der Erkrankung beeinflußt.

\section{Résumé}

Essai randomisé sur la correction des surfaces occlusales dans le traitement des patients atteints de parodontite

Le but de cet essai clinique randomisé était de tester: (1) l'influence de la correction des surfaces occlusales (occlusal adjustment $=\mathrm{OA}$ ) associé au traitement parodontal sur le niveau de l'attache, la profondeur des poches et la mobilité dentaire, (2) si OA a plus d'influence sur les lésions parodontales traitées sans intervention chirurgicale et (3) si la mobilité dentaire initiale ou la sévérité de l'atteinte avaient une influence sur le niveau de l'attache après traitement quand on avait pratiqué une OA. Après une phase hygiénique de traitement, 50 patients ont été affectés par tirage au sort à un groupe OA ( 22 sujets), chez lesquels on pratiquait la correction des surfaces occlusales, ou à un groupe No $\mathrm{OA}$ (28 patients) sans correction des surfaces occlusales. Suivant la mé- thode de bouche divisée (split-mouth) par tirage au sort des côtés chez chacun des patients, un parodontiste a pratiqué chez tous les patients une opération à lambeau de Widman modifiée (MWF) d'un côté et un détartrage avec surfaçage radiculaire (SRP) de l'autre côté. Après le traitement actif, les patients recevaient un traitement de maintenance avec nettoyage tous les 3 mois et enregistrement annuel des scores. Pour l'analyse de ces données sur 2 ans, une analyse de variance des mesures répétées a été pratiquée, en se servant du changement du niveau de l'attache et des profondeurs de poches comme indicateurs des résultats. Il y avait un gain d'attache parodontale clinique significativement plus élevé chez les patients ayant reçu OA. Les côtés de la bouche, traités chirurgicalement ou non, réagissait de la même manière à OA. OA n'avait pas d'influence sur la façon dont réagissaient les profondeurs de poches; la mobilité dentaire initiale et la sévérité initiale de la maladie parodontale restaient sans influence sur la réponse à $\mathrm{OA}$.

\section{References}

Ericsson, J. \& Lindhe, J. (1977) Lack of effect of trauma from occlusion on the recurrence of experimental periodontitis. $J$. Clin. Periodont. 4, 115-127.

Ericsson, J. \& Lindhe, J. (1982) Effect of longstanding jiggling on experimental marginal periodontitis in the beagle dog. $J$. Clin. Periodont. 9, 497-503.

Ericsson, J. \& Lindhe, J. (1984) Lack of significance of increased tooth mobility in experimental periodontitis. J. Periodont. 55, 447-452.

Fleszar, T. J., Knowles, J. W., Morrison, E. C., Nissle, R. R. \& Ramfjord, S. P. (1980) Tooth mobility and periodontal therapy. J. Clin. Periodont. 7, 495-505.

Glickman, J., Smulow, J. B., Vogel, B. \& Passamonti, G. (1966) The effect of occlusal forces on healing following mucogingival surgery. J. Periodont. 37, 319-325.
Hill, R. W., Ramfjord, S. P., Morrison, E. C., Appleberry, E. A., Caffesse, R. G., Kerry, G. J. \& Nissle, R. R. (1981) Four types of periodontal treatment compared over two years. J. Periodont. 53, 655-662.

Kantor, M., Polson, A. M. \& Zander, H. A. (1976) Alveolar bone regeneration after removal of inflammatory and traumatic factors. J. Periodont. 47, 687-695.

Kaufman, H., Carranza, F. A. Jr., Endres, B., Newman, M. G. \& Murphy, X. I. (1984) The influence of trauma from occlusion on the bacterial repopulation of periodontal pockets in dogs. J. Periodont. 55, 86-92.

Knowles, J. W., Burgett, F., Nissle, R. R. et al. (1979) Results of periodontal treatment related to pocket depth and attachment level: Eight years. J. Periodontol. 50, 225.

Lang, N. P., Gusberti, T. A. \& Siegrist, B. E. (1985) Aetiologie der Parodontalerkrankungen. Schew. Montas. Zahnmed. 95, 59-70.

Lindhe, J. \& Ericsson, J. (1976) The influence of trauma from occlusion on reduced but healthy periodontal tissues in dogs. J. Clin. Periodont. 3, 110-122.

Lindhe, J. \& Nyman, S. (1975) The effect of plaque control and surgical pocket elimination on the establishment and maintenance of periodontal health. A longitudinal study of periodontal therapy in cases of advanced disease. J. Clin. Periodont. 2, 67-79.

Lindhe, J. \& Svanberg, G. (1974) Influence of trauma from occlusion on progression of experimental periodontitis in the Beagle dog. J. Clin. Periodont. 1, 3-14.

Meitner, S. (1975) Codestructive factors of marginal periodontitis and repetative mechanical injury. J. Dent. Res. 54, Special Issue C: C78-C85.

Morrison, E. C., Ramfjord, S. P. \& Hill, R. W. (1980) Short-term effect of initial nonsurgical periodontal treatment (hygienic phase). J. Clin. Periodont 7, 199-211.

Muhlbradt, L. (1972) Entzundung Zahnfleischtaschen und Zahnlocherung in ihren statistichen Beziehungen. D.Z.Z. 27, 311-316.

Muhlemann, H. R., Herzog, H. \& Rateitschack, K. H. (1957) Quantative evaluation of the therapeutic effect of selective $g$ grinding. J. Periodont. 28, 11-16.

Nyman, S. \& Lindhe, J. (1976) Persistant tooth hypermobility following completion of periodontal treatment. J. Clin. Periodont. 3, 81-93.

Nyman, S., Lindhe, J. \& Ericsson, J. (1978) The effect of progressive tooth mobility on destructive periodontitis in the dog. $J$. Clin. Periodont. 5, 213-225.

Nyman, S., Rosling, B. \& Lindhe, J. (1975) Effect of professional tooth cleaning on healing after periodontal surgery. $J$. Clin. Periodont. 2, 80-86.

Polson, A. M., Meitner, S. W. \& Zander, H. A. (1976) Trauma and progression of marginal periodontitis in squirrel monkeys (III). Adaptation of interproximal alveolar bone to repetitive injury. J. Periodont. Res. 11, 279-289. 
Ramfjord, S. P. \& Ash, M. M. Jr. (1981) Significance of occlusion in the etiology and treatment of early, moderate and advanced periodontitis. J. Periodont 52, 511-517.

Ramfjord, S. P., Caffesse, R. G., Morrison, E. D., Hill, R. W., Kerry, G. J., Appleberry, E. A., Nissle, R. R. \& Stults, F. L. (1987) Four Modalities of Periodontal Treatment Compared over Five Years. J. Clin. Periodont. 14, 445-452.

Ramfjord, S. P. \& Nissle, R. R. (1974) The modified Widman flap. J. Periodont. 45, 601-607.
Renggli, H. H. \& Muhlemann, H. R. (1970) Zahnbeweglichkeit, marginale Parodontal entzundung und oklusales trauma. Parodontologie 24, 39-48.

Svanberg, G. (1974) Influence of trauma from occlusion on the periodontium of dogs with normal or inflamed gingiva. Odont. Revy. 25, 165-178.

Vollmer, W. H. \& Rateitschack, K. H. (1975) Influence of occlusal adjustment by grinding on gingivitis and mobility of traumatized teeth. J. Clin. Periodont. 2, 113125.
Address:

F. G. Burgett

University of Michigan

School of Dentistry

Periodontics

Ann Arbor, Michigan 48109-1078

USA 
This document is a scanned copy of a printed document. No warranty is given about the accuracy of the copy. Users should refer to the original published version of the material. 